\title{
Gender Comparison of the Performance of Secondary Level Institutional Heads in DIK, Khyber Pakhtunkhwa
}

\author{
Dr Asif Jamil \\ Associate Professor, Institute of Education and Research Gomal University Dera Ismail \\ Khan, KP \\ E-mail: asifjamil72@hotmail.com
}

Amina Ramzan

MEd Distance Education IER, Gomal University Dera Ismail Khan, KP

Malik Amer Atta

Assistant Professor, Institute of Education and Research Gomal University Dera Ismail Khan, KP

Muhammad Younis

Lecturer, GDC \# 2, Dera Ismail Khan, Khyber Pakhtunkhwa

Uzma Kareem

MPhil Student IER, Gomal University DIKhan Khyber Pakhtunkhwa

Tahirullah Jan

MPhil Student IER, Gomal University DIKhan Khyber Pakhtunkhwa

Doi:10.5296/ijhrs.v2i3.2452 URL: http://dx.doi.org/10.5296/ijhrs.v2i3.2452

\begin{abstract}
This study was done keeping in view importance of the role of administrators in the success of educational institutions. The prime focus was comparison of the effectiveness of male and female Institutional heads working in different secondary schools of district Dera Ismail Khan, situated in the south of Khyber Pakhtunkhwa province of Pakistan. Major areas of comparison remained percepts, leadership styles and efficiency of the Institutional heads, perceived by the teachers appointed in respective schools. Findings of the study revealed that female Institutional heads prove to be comparatively better administrators showing keen interest in institutional administration, motivating their team for hard work and keeping coordinal relationship with staff and parents.
\end{abstract}


KEYWORDS: Gender, Performance, Secondary Level, Institutional Heads

\section{INTRODUCTION}

Prime importance is given to the secondary education institution as it works as a bridge between elementary and tertiary level of education. Institutional Head is supposed to play very important rather pivotal role in the administration of institution. All sorts of commendations (in case of success) and censures (in case of omission) ultimately result from the way administration is run.

Lots of duties are supposed to be done by the Institutional heads including administration of curriculum and teaching, assessment, evaluation and examination, resource allocation, costing and forward planning, staff appraisal, relationship with community and use of practical skills necessary for surviving the policies of organization (Ojo, 1999). It is a fact that the aims and objectives of education cannot be achieved until and unless educational policies are properly implemented which is the basic responsibility of Institutional Heads. They are supposed to plays very active part in formation and execution of organizational policies and must be a change agent to face the incoming challenges of the system. According to Frase and Hetzel (1990) the Institutional Head must work outside the classroom, actively interact with community, and demonstrate the purpose and strategies of institutional plan, mission and vision. In this respect involvement of parents and community play an important role and help in institutions development and improvement. For this purpose, the institution Institutional Head must be active for adopting the new development and have the abilities of adapting to the new changes (Al-Ani and Amzat, 2004).

According to Maduabum (2002) Institutional Head is a planner, director, controller, coordinator, organizer, advisor and a problem solver. The Institutional Head is a person who identifies and shoulders the set goals and objectives of institution which are according to national needs. It is a fact that countries that have an effective system of educational administration also happen to be the leaders of the world, both socially and economically. The major responsibility of institution Institutional Head is to uplifts the standard of teaching and learning in classroom. He/she must be capable of supporting teachers, classroom instruction through instructional supervision, professional development and classroom resources and the extent to which these instructional supports were affecting. Research reveals that Institutional Head's confidence push up teachers in classroom activities and their participation in instructional leadership program.(Sindhvad,2009).

Timilehin (2010) investigated for the reason of poor quality outputs from secondary institutions in Nigeria. Findings of the study reveal that insufficient funding, deficient facilities, less job satisfaction of teachers, frequent changes in education policies and poor administration of institution were the major causes of poor quality. According to Foster and Boloz (1980) the administrator should be aware of goals and the objectives of the Institution, and should adopt correct leadership style for promotion of the institution in desirable direction. If personal power of administrator is more important than organizational success, the institution will remain unsuccessful and subordinates less satisfied.

Gender of the Institutional Heads differently influences during childhood with family issues and throughout their professional adult lives. In many developing countries female 
Institutional Heads got their positions either "by chance" or by clear career planning and aspiration into Institutional headship. Major factor that affects the difference between male and female working as administrators is their family responsibilities and marital status (Lad's, 2000).

Reasonable number of female is involved in educational administration i.e. Institutional Headship in many parts of the world including Korea (Kim and Kim, 2005), China (Su et al., 2000), Trinidad and Tobago (Morris, 1999) and Singapore (Morris et al., 1999); whereas a moderate number of female is involved in the administrative process in Muslim countries also like Turkey (Celikten, 2005) and Pakistan (Kirk, 2004).

There are two views about the difference of leadership stance of male and female. Some researchers found no gender difference in educational leadership (Jirasinghe and Lyons, 1996; Mertz and McNeely, 1998). Others say that men and women differ in the ways they manage people. Generally it is considered that female Institutional heads tend to adopt a democratic and cooperative style, to pay more importance to vision building for institution, to spend much time to bring change and implement the change and to solve curriculum and teaching matters (Acker, 1989; Eagly et al., 1992; Fennell, 1999;Marshall,1995;Oplatka,2003; Shakesshaft,1989). A study conducted in Namibia concluded that, woman Institutional heads are more effective than their male counterparts, because they are caring, well organized and good at communicating and establishing relations with others, although these qualities contradicts from their nature (Kawana, 2004).

Al-Ani \& Amzat, (2011) posit that basic institution's female Heads are more successful than male administrators in getting institutional mission and vision, developing knowledge and institutional environment, participation of community and administration of institutional building. On the other hand same study indicates that male Head are more competent to hold up the planning and development. Result of study conducted by Akiri and Ugborugbo (2008) indicates that there is no prominent difference in the work of male and female teachers, however the female teachers are generally less productive than male teachers. Male teachers are less influenced by location than female counterparts. The study suggests that female teachers should be posted in urban and semi urban areas, while male teachers can be are appointed in rural institutions. According to Celikten (2005) the valuable property of successful institutions is the Institutional Head and his/her ability to uplift morale of teachers instead of demoralizing them. Teachers believe that female Institutional heads keep friendly environment in institution, in such a way that they tend to hear personal problems of teachers. Female Institutional heads are usually not autocratic like their male counterparts. Research indicates that female are more active on issues of institution, administration and academic achievement than their counterparts whether it is leadership, evaluation, professional development etc. Females have higher enrollment in Universities and colleges in Pakistan as compared to males. Reason of female's success in the teaching sectors is their commitment, dedication and efficiency. Females work hard in getting the institutional mission and vision and endeavor for development of institution environment, partnership of community.

A study was conducted on task oriented leader that deal with task accomplishment and on people oriented leaders that deal with satisfaction of employees. The task centered leader gives no importance to satisfaction of employees and cohesiveness and are called 
autocratic restrictive, socially distant directive and structural. According to Stogdill,(1974) task centered leaders are mostly concerned with production but their autocratic styles tend to inhibit it while their socially directive styles are concerned with productivity. People centered leaders are not consistently related to productivity nor did they enhance satisfaction of employees. They are called democratic, permissive, follower oriented, participative and considerate. Task centered leader accomplish the desired direction and people centered promote employee satisfaction and cohesiveness of group. Due to various reasons the female cannot use their own decision power in leadership positions. There may be the lack of necessary aspiration, lack of awareness of promotion system and a lack of confidence for success, gender based socialization, fear of failure etc. (Acker, 1989; Coffey and Delamont, 2000; Limerick and Anderson, 1999).

The successful leaders have greater needs for achievement and lower need for power. This achievement orientation tends to be compatible with the aggressive behavior that the organization needs for success, while the low need for power is channeled into hiring of highly trained professionals whose technical abilities are able to contribute to the organization's success. But the leader with a high need for power and low need for achievement tend to hire subordinates who are less qualified professionally. So, higher the leader's need for achievement, the greater the organization's success, while higher the leader's need for power, the lower the organization's success.

\section{METHODS AND MATERIALS}

This study was designed to estimate and compare the performance of male and female Institutional Heads appointed in the secondary schools of Dera Ismail Khan which a southern district of Khyber Pakhtunkhwa province of Pakistan. The population for the study comprised of all the teachers working in public secondary schools of the district for being the best judges of the performance of their heads, to estimate and compare performance of the male and female Institutional Heads. A total of twenty public schools, ten male and ten female were selected randomly whereas six teachers from each school were taken using simple random sampling technique for the collection of data. The sample for data collection thus consisted of 120 i.e. sixty male and sixty female teachers working in the respective secondary schools. Structured questionnaires were used as instrument for data collection which was built on a five point Likert scale ranging from 'excellent' to 'very poor'. The instrument consisted of thirty-five items related to the problem. Cronbach's alpha was used for checking the reliability of the measuring scale which remained as 0.813 .The researcher administered the questionnaire with the help of co-researchers. Collected data were entered in the SPSS (statistical package for social sciences) for its statistical analysis, whereas in addition to the descriptive analysis of the data; independent sample $t$-test was applied for comparison of the performance of male and female Institutional Heads.

\section{Major areas for Comparison of the performance of Institutional Heads based on following presumptions:}




\section{Macrothink $\Delta$ Institute ${ }^{\mathrm{m}}$}

1. Male administrators more successfully promote cooperation and develop consensus.

2. Female administrators give due share to their subordinates in decision making.

3. Male administrators succeed in inspiring and getting their colleagues to follow.

4. Male administrators are strict in maintaining discipline in the schools.

5. Female administrators keep friendly atmosphere through mutual respect and love.

6. Female administrators try their best to avoid negative criticism.

7. Female administrators involve their staff in setting objectives.

8. Female administrators are more effective leaders.

\section{RESULTS AND DISCUSSION}

Descriptive analysis of data on standing of Institutional Heads

\begin{tabular}{|c|c|c|c|c|c|c|c|c|c|c|}
\hline \multirow[t]{2}{*}{ Statement } & \multicolumn{10}{|c|}{$\begin{array}{l}\text { Scores achieved by Institutional Heads in perspective of their performance( in } \\
\text { percentage) }\end{array}$} \\
\hline & \multicolumn{2}{|c|}{ Excellent } & \multicolumn{2}{|c|}{ Good } & \multicolumn{2}{|c|}{ Satisfactory } & \multicolumn{2}{|c|}{ Poor } & \multicolumn{2}{|l|}{ Worst } \\
\hline \multirow[t]{2}{*}{$\begin{array}{l}\text { Promote cooperation } \\
\text { and consensus }\end{array}$} & $\begin{array}{l}\text { Mal } \\
\text { e }\end{array}$ & $\begin{array}{l}\text { Femal } \\
\text { e }\end{array}$ & $\begin{array}{l}\text { Mal } \\
\text { e }\end{array}$ & $\begin{array}{l}\text { Femal } \\
\text { e }\end{array}$ & $\begin{array}{l}\text { Mal } \\
\text { e }\end{array}$ & $\begin{array}{l}\text { Femal } \\
\text { e }\end{array}$ & $\begin{array}{l}\text { Mal } \\
\text { e }\end{array}$ & $\begin{array}{l}\text { Femal } \\
\text { e }\end{array}$ & Male & $\begin{array}{l}\text { Fema } \\
\text { le }\end{array}$ \\
\hline & 26.9 & 40.0 & 26.9 & 40.0 & 26.9 & 20.0 & 15.4 & 0.0 & 3.8 & 0.0 \\
\hline $\begin{array}{l}\text { Involve subordinates in } \\
\text { decision making. }\end{array}$ & 23.1 & 46.7 & 26.9 & 30.0 & 23.1 & 23.3 & 7.7 & 0.0 & 19.2 & 0.0 \\
\hline $\begin{array}{l}\text { Succeed in inspiring and } \\
\text { getting others to follow. }\end{array}$ & 19.2 & 33.3 & 23.1 & 30.0 & 19.2 & 36.7 & 19.2 & 0.0 & 19.2 & 0.0 \\
\hline $\begin{array}{l}\text { Strict in maintaining } \\
\text { Discipline }\end{array}$ & 15.4 & 30.0 & 11.5 & 20.0 & 26.9 & 30.0 & 11.5 & 3.3 & 34.6 & 16.7 \\
\hline $\begin{array}{l}\text { Keep friendly } \\
\text { atmosphere with love } \\
\text { and mutual respect }\end{array}$ & 15.4 & 63.3 & 30.8 & 26.7 & 23.0 & 10.0 & 15.4 & 0.0 & 15.4 & 0.0 \\
\hline $\begin{array}{l}\text { Avoid negative } \\
\text { criticism. }\end{array}$ & 30.8 & 43.3 & 19.2 & 36.7 & 34.6 & 13.3 & 7.7 & 6.7 & 7.7 & 0.0 \\
\hline $\begin{array}{l}\text { Use staff involvement in } \\
\text { setting objectives. }\end{array}$ & 11.5 & 85.0 & 26.9 & 56.3 & 19.2 & 44.4 & 26.9 & 0.0 & 15.4 & 0.0 \\
\hline $\begin{array}{l}\text { Prove to be effective } \\
\text { leader. }\end{array}$ & 23.1 & 40.0 & 23.1 & 40.0 & 34.6 & 20.0 & 7.7 & 0.0 & 11.5 & 0.0 \\
\hline Overall standing & 20.6 & 42.7 & $\begin{array}{l}23.5 \\
5 \\
\end{array}$ & 34.96 & $\begin{array}{l}25.9 \\
3 \\
\end{array}$ & 24.71 & $\begin{array}{l}13.9 \\
3 \\
\end{array}$ & 1.25 & 15.85 & 2.08 \\
\hline
\end{tabular}


Results of $t$-test showing comparative status of male and Female Institutional Head

\begin{tabular}{|c|c|c|c|c|c|c|c|}
\hline Attribute & Gender & $\begin{array}{l}\mathrm{n} \\
120\end{array}$ & $\mathrm{X}$ & $\mathrm{S}$ & $t$-value & $\begin{array}{l}\text { Table } \\
\text { value }\end{array}$ & $\alpha$ \\
\hline \multirow{2}{*}{$\begin{array}{l}\text { Cooperation and } \\
\text { consensus }\end{array}$} & $\mathrm{M}$ & 60 & 3.58 & 1.172 & \multirow[t]{2}{*}{2.389} & \multirow[t]{2}{*}{1.960} & \multirow[t]{2}{*}{0.05} \\
\hline & $\mathrm{F}$ & 60 & 4.20 & .761 & & & \\
\hline \multirow{2}{*}{$\begin{array}{l}\text { Inclusive decision } \\
\text { making }\end{array}$} & $\mathrm{M}$ & 60 & 2.92 & 1.294 & \multirow[t]{2}{*}{5.476} & \multirow[t]{2}{*}{1.960} & \multirow[t]{2}{*}{0.05} \\
\hline & $\mathrm{F}$ & 60 & 4.43 & .728 & & & \\
\hline \multirow{2}{*}{$\begin{array}{l}\text { Inspiration and } \\
\text { getting others to } \\
\text { follow }\end{array}$} & $\mathrm{M}$ & 60 & 3.04 & 1.428 & \multirow[t]{2}{*}{3.002} & \multirow[t]{2}{*}{1.960} & \multirow[t]{2}{*}{0.05} \\
\hline & $\mathrm{F}$ & 60 & 3.97 & .850 & & & \\
\hline \multirow{2}{*}{$\begin{array}{l}\text { Maintenance of } \\
\text { Discipline }\end{array}$} & $\mathrm{M}$ & 60 & 2.62 & 1.472 & \multirow[t]{2}{*}{2.124} & \multirow[t]{2}{*}{1.960} & \multirow[t]{2}{*}{0.05} \\
\hline & $\mathrm{F}$ & 60 & 3.43 & 1.406 & & & \\
\hline \multirow{2}{*}{$\begin{array}{l}\text { Creation of } \\
\text { friendly atmosphere }\end{array}$} & $\mathrm{M}$ & 60 & 3.15 & 1.317 & \multirow[t]{2}{*}{5.018} & \multirow[t]{2}{*}{1.960} & \multirow[t]{2}{*}{0.05} \\
\hline & $\mathrm{F}$ & 60 & 4.53 & .681 & & & \\
\hline \multirow[t]{2}{*}{ Negative criticism } & M & 60 & 3.58 & 1.238 & \multirow[t]{2}{*}{2.046} & \multirow[t]{2}{*}{1.960} & \multirow[t]{2}{*}{0.05} \\
\hline & $\mathrm{F}$ & 60 & 4.17 & .913 & & & \\
\hline \multirow{2}{*}{$\begin{array}{l}\text { staff involvement in } \\
\text { setting objectives }\end{array}$} & $\mathrm{M}$ & 60 & 3.27 & 1.430 & \multirow[t]{2}{*}{3.149} & \multirow[t]{2}{*}{1.960} & \multirow[t]{2}{*}{0.05} \\
\hline & $\mathrm{F}$ & 60 & 4.23 & .817 & & & \\
\hline \multirow{2}{*}{$\begin{array}{lr}\text { Considered } & \text { as } \\
\text { Effective leaders }\end{array}$} & $\mathrm{M}$ & 60 & 3.38 & 1.267 & \multirow[t]{2}{*}{2.963} & \multirow[t]{2}{*}{1.960} & \multirow[t]{2}{*}{0.05} \\
\hline & $\mathrm{F}$ & 60 & 4.20 & .761 & & & \\
\hline
\end{tabular}

Independent sampled $t$-test was applied to compare the status of male and female administrators on different aspects relating to their performance as the Institutional heads at secondary level. With reference to effectiveness of male and female administrators concerning promotion of cooperation and consensus within the institution for achievement of Institutional goals, the mean score of the female administrators i.e. 4.20 for being bigger than that of the male administrators i.e. 3.58 and standard deviations of 0.761 and 1.172 respectively for female and male administrators revealed that female had more positive approach towards creation of a cooperative environment and development of consensus for the achievement of set Institutional goals. Similarly the calculated t-value 2.389 was found as greater than the tabulated $t$ value 1.960; hence statistical analysis of data affirmed the presumed stance of the researchers. While measuring the difference of approach between male and female Institutional heads regarding inclusive decision making it was found that mean score of female i.e. 4.43 was very much greater than that of male i.e. 2.92 whereas the standard deviation remained as 0.728 and 1.294 respectively for female and male. Likewise calculated t-value 5.476 was found too much greater than that of tabulated t-value i.e. 1.960. The results showed that female administrator give much more respect to subordinates for decision making than male administrator. Consequent upon data analysis through the application of independent sampled $t$-test for determining the difference of approach of the under study group for inspiring and getting others (subordinates/colleagues) do maximum to their potentials for the betterment of Institution, it was found that mean score of female 
administrators i.e. 3.97 was considerably bigger than that of male administrators i.e. 3.04, with SD of 0.850 and 1.428 respectively for female and male administrators. The calculated t-value 3.002 was also found as greater than tabulated t-value 1.960 which did show that female Institutional heads were more successful in inspiring and getting others to follow them and therefore prove to be more productive in getting their fellows work to the maximum of their potentials. Results of the independent sampled $t$-test for evaluating the conscientious of male and female Institutional heads in maintaining the discipline within their institution produced mean score for the female administrator i.e. 3.43 which proved to be greater than that of male administrator i.e. 2.62 with a standard deviation of 1.406 and 1.472 respectively for female and male. Similarly, the calculated t-value -2.124 was found as greater than tabulated t-value 1.960. The analyzed data thus revealed that female proved to be more painstaking in maintenance of the school discipline.

For indentifying the difference of approach among the two groups under study in keeping a good friendly atmosphere in the institution, based on mutual respect and love; the independent sampled $t$-test scores produced a mean score of 4.53 for female administrators and 3.15 for the male institutional heads with a standard deviation of 0.681 and 1.317 respectively for female and male administrators. The calculated t-value 5.018 remained too much greater than tabulated t-value i.e. 1.960. According to the results the females were found having much more positive approach toward creation of friendly atmosphere based on mutual understanding and love in their administrated Institutions, as compared to their male counterparts.

Deviation in the style of male and female administrator concerning negative criticism on their subordinates was also measured for being one of the significant administrative issue that plays important role in determining the effectiveness of administration as fellow workers and subordinates usually dislike it and their performance is adversely effected if the administrator uses to criticize every action of his fellows. The mean scores obtained through independent sampled $t$-test for male Institutional heads i.e. 3.58 proved to be lesser less than that of female administrator i.e. 4.17. The standard deviation was found as 1.238 and 0.913 for male and female respectively. Calculated t-value remained as 2.046 which were bigger than tabulated t-value i.e. 1.960. It was thus acquired from the results that the extent of female Institutional heads in doing negative criticism on their subordinates and fellow teachers was comparatively lesser than that of the male Institutional heads. To know the preferences of male and female Institutional heads regarding collective objective setting or staff involvement in setting objectives, the mean scores of female i.e. 4.23 were calculated as comparatively much greater than that of male i.e. 3.27 with a standard deviation of 0.817 and 1.430 for female and male respectively. Similarly calculated t-value 3.149 was found as greater than that of tabulated t-value i.e. 1.960. The results showed that female administrator kept their team together in setting objectives of the Institution. To sum up all the above research questions, the respondents were asked to categorically declare as to who was more effective administrator for secondary schools. The application of independent sampled $t$-test produces mean score of the female administrators as 4.20 which proved to be considerably greater than that of male administrator i.e. 3.38 with standard deviation scores of 0.761 and 1.267 respectively for female and male Institutional heads. Similarly the calculated t-value 
-2.963 was found greater than that of tabulated t-value i.e. 1.960. The results thus revealed that female administrator have excellent leadership skills than male administrator and prove to be more skillful and effective leaders than male counterparts.

Analysis of the data reveal that females Institutional Heads working in the secondary schools are considered to be comparatively good administrators and show better organizational, administrative and leadership skills than male administrators. It was interesting to note that at one hand the female Institutional heads were believed as comparatively more strict administrators but on the other and they were specifically rated very high in creation of friendly atmosphere in the institute and making inclusive decisions. It simply means that they were successful in maintaining a balance between sustentation of discipline and creation of friendly climate in the Institute, for the reason that they were more successful in winning the trust and confidence of their subordinates. Thus, on the whole the female administrators were supposed to be comparatively more effective leaders as Institutional heads of the secondary schools in comparison to their male counterparts

\section{REFERENCES}

- Acker, S. (1989), Teachers, Gender and Careers, Falmer Press, London

- Akiri, A and Ugdorugbo, N, M. (2008) “An examination of gender's influence on teachers productivity in secondary schools" journal of social science: 17 (3) pp. 185-191

- Al-Ani, W, T, K and Amzat, I, H. (2011) "Basic education school administrators perceptions towards sustainable planning development in Sultanate of Oman" American journal of scientific research: pp. 122-134.

- Anonymous (2006) Iowa's_School Leadership Standards_and Criteria. Available on web address, www.elps.hs.iastate.edu/edadm/document/ISSL\%20Standards.pdf. 15 March 2012.

- Celikten, M. (2005), “A perspective on women principals in Turkey", International Journal of Leadership in Education, Vol. 8 No. 3, pp. 207-21.

- Coffey, A. and Delamont, S. (2000), Feminism and the Classroom Teacher: Research, Praxis, Pedagogy, Routledge/Falmer, London

- Eagly, A.H., Karau, S.J. and Johnson, B.T. (1992), “Gender and leadership style among school principals: a meta-analysis”, Educational Administration Quarterly, Vol. 28 No. 1,pp. 76-102.

- Evetts, J. (1994), "Gender and secondary headship: managerial experiences in teaching”, in Evetts, J. (Ed.), Women and Career, Longman, London, pp. 157-69.

- Fennell, H.A. (1999), "Power in the principalship: four women's experiences”, Journal of Educational Administration, Vol. 37 No. 1, pp. 23-49.

- Foster, C, G and Boloz, S, A. (1980) "The BIA school administrator and effective leadership" journal of American Indian education: 19 (2) pp. 1-4.

- Frase, L, and Hetzel, R. (1990) “School management by wandering around”. Economic publishing company, Inc USA. 
- Hall, V. (1996), Dancing on the Ceiling: A Study of Women Managers in Education, Paul Chapman, London

- Jirasinghe, D. and Lyons, G. (1996), the Competent Dead: A Job Analysis of Heads' Tasks and Personality Factor, Falmer Press, London.

- Kawana, I. (2004) "Inspectors of educations perceptions of female principalship in the Rundu region of Namibia.

- Kim, S. and Kim, E.P. (2005), "Profiles of school administrators in South Korea", Educational Management, Administration and Leadership, Vol. 33 No. 3, pp. 289-310.

- Kirk, J. (2004), "Impossible fictions: the lived experiences of women teachers in Karachi”, Comparative Education Review, Vol. 48 No. 4, pp. 374-95.

- Lad, K. (2000), “Two women high school principals: the influence of gender on entry into education and their professional lives", Journal of School Leadership, Vol. 12, pp. 663-89.

- Limerick, B. and Anderson, C. (1999), "Female administrators and school-based management", Educational Management and Administration, Vol. 27 No. 4, pp. 401-14.

- Maduabum, M, A. (2000) "Occupational stress factors among secondary school principals in Abia state, Nigeria". International journal of educational planning and administration. 1(1): pp. 17-27.

- Marshall, C. (1995), "Imaging leadership”, Educational Administration Quarterly, Vol. 31 No. 3, pp. 484-92.

- Mertz, N. and McNeely, S.R. (1998), "Women on the job: a study of female high school principals", Educational Administration Quarterly, Vol. 34 No. 2, pp. 196-222.

- Morris, J. (1999), "Managing women: secondary school principals in Trinidad and Tobago", Gender and Education, Vol. 11 No. 3, pp. 343-55.

- Morriss, S.B., Tin, L.G. and Coleman, M. (1999), "Leadership stereotypes and styles of female Singaporean principals”, Compare, Vol. 29 No. 2, pp. 191-202.

- Ojo, K. (1999). "Administration and management of secondary education in Ekiti state our experience and anxieties. In D. Ajayi and S. Ibitola (eds) effective management of secondary school: the principals challenge. Ibadan Adeose publications. Pp. 9-20.

- Oplatka, I. (2003), "School change and self-renewal: some reflections from life stories of women principals", Journal of Educational Change, Vol. 4 No. 1, pp. 25-43.

- Oplatka, I. (2006), "Women in educational administration within developing countries towards a new international research agenda" Journal of educational administration: 44(6), pp. 604-624.

- Oplatka, I. and Atias, M. (n.d.), "Gendered views of managing discipline in school and class", Gender and Education, in press.

- Regan, H.B. and Brooks, G.H. (1995), Out of Women's Experience: Creating Relational Leadership, Corwin Press, Thousand Oaks, CA.

- Shakeshaft, K. (1989), Women in Educational Administration, Corwin Press, Newbury Park, CA.

- Sindhbad, S, P. (2009) "School principal as instructional leader and investigation of school leadership capacity in Filipin. 
- Stogdill and Ralph, M. (1974) Handbook of leadership, the free press, New York.

- Su, Z., Adams, J.P. and Miniberg, E. (2000), "Profiles and preparation of urban school principals: a comparative study in the United States and China", Education and Urban Society, Vol. 32 No. 4, pp. 455-80.

- Timilehin, E, H. (2010) "Administering secondary school in Nigeria for quality output in the $21^{\text {st }}$ century: the principal's challenge". European journal of educational science: 2 (3) pp. 187-192. 